\title{
28 Research Square \\ Carbon Status and Regression Model for Tree Carbon by Crown Cover for Sal Forest of Nepal
}

Prashant Paudel ( $\sim$ prashant.paudel88@gmail.com )

Faculty of Forestry https://orcid.org/0000-0003-0982-4818

\section{Rupesh Kalakheti}

Faculty of Forestry, Agriculture and Forestry University

\section{Tek Maraseni}

Center for Sustainable Agriculture System, University of Southern Queensland

\section{Research}

Keywords: Sal forest, Crown cover, carbon stock, estimation, model

Posted Date: December 23rd, 2019

DOI: https://doi.org/10.21203/rs.2.19432/v1

License: (1) This work is licensed under a Creative Commons Attribution 4.0 International License. Read Full License 


\section{Abstract}

Volume, biomass and carbon of forest ecosystem are generally estimated using lookup tables or allometric equations known as models. These general equation-based models are usually exclusively based on dimensional measurement such as diameter at breast height (DBH) and/or height, which sometimes makes it difficult to judge applicability of equation to given forest condition or types. It is therefore important to estimate carbon stock and develop models to predict biomass or carbon stock with stratification by categorical variables like crown cover, slope, forest types, etc. Stratification of forest by remote sensing approach while designing forest inventory not only improves the reliability of the estimation but also reduces the cost of measurement. Taking crown coverage $(<25 \%, 25-50 \%, 50-75 \%$ and $>75 \%$ ) as a categorical variable, this study assessed the status of carbon stock and develop a regression model to predict carbon stock for each canopy class of Sal (Shorea robusta) forest in Nepal. DBH and height were measured for trees with more than $7 \mathrm{~cm} \mathrm{DBH}$ in 82 sample plots $(18,22,22$ and 20 for $<25 \%$, $25-50 \%, 50-75 \%$ and $>75 \%$ respectively). On average 297 stands per hectare were recorded with $94.80 \mathrm{~m} 3$ /ha growing stock. Carbon stock was highest for $>75 \%$ crown cover class ( 89.83 ton $\mathrm{C} / \mathrm{ha}$ ) and lowest for $<25 \%$ crown cover class ( 27.47 ton $\mathrm{C} / \mathrm{ha}$ ) with average 60.41 ton $\mathrm{C} / \mathrm{ha}$, where per tree carbon stock was lowest in crown cover class $25-50 \%$ ( 0.16 ton $\mathrm{C} /$ tree). TukeyHSD shows that four pairs of crown cover classes have significant difference in carbon stock at $95 \%$ confidence interval. Regression model with natural logarithm of DBH 2 and total tree height was best fitted for estimation of carbon stock per tree in different crown cover class with adjusted R $2>0.99$ and residuals were normally distributed. Adjustment of model (natural logarithm of DBH 2 and height) with high accuracy (R $2>0.99$ ) shows the importance of stratification especially by crown cover for accurate estimation of carbon stock for optimization of carbon benefits.

\section{Background}

Forest ecosystem stores carbon by sequestering a substantial amount of carbon dioxide from the atmosphere, globally accounting around $92 \%$ of all terrestrial biomass storing approximately $400 \mathrm{Gt}$ of carbon (Dixon et al. 1994; IPCC 2014; MacDicken 1997; Maraseni and Pandey 2014). Different literature indicates that the amount of carbon stored in forest differs according to the spatial and temporal factors (Karki et al. 2016; Pandey and Bhusal 2016; Wei et al. 2013) such as forest types (Jina et al. 2009), size, age (Wei et al. 2013), stand structure, associated vegetation (Jina et al. 2009), ecological zonation (Wei et al. 2013), silvicultural treatments (Pandey et al. 2014), forest management intensities and modalities

(Pandey et al. 2019; Parrotta, Wildburger, and Mansourian 2012; Le Quéré et al. 2009; Scott et al. 2004; Sharma and Kakchapati 2018; Tashi et al. 2017) etc. Yohannes and Soromessa (2015) estimated 324.79 ton/ha above ground carbon in lower slope compared to 187.49 ton/ha in higher slope and also concluded that variation in total carbon stock by aspect for Gedo forest of Ethiopia. An experiment conducted in mixed deciduous and evergreen broadleaf forest by International Center for Integrated Mountain Development (ICIMOD) knowledge park Nepal shows that the carbon stock density of dense forest strata was higher than that of the sparse strata, whereas soil organic carbon was lower (164.02 ton 
$\mathrm{C} / \mathrm{ha}$ ) in dense forest strata compared to in sparse strata (180.93 ton $\mathrm{C} / \mathrm{ha}$ ) in which mean soil organic carbon (fine fractions) percentage was $5.27 \%$ and $6.01 \%$ for sparse and dense forest strata, respectively (Karki et al. 2016). Similarly, Sharma and Kakchapati (2018) also concluded that the stem density has significant association with the total biomass carbon content, where plots with less than 20 trees per plot showed higher carbon stock.

The carbon stock estimation equation for forest ecosystem has shown significant statistical dependence with the factors like DBH, stem volume, stand density, crown dimensions and management modalities (Ni-Meister et al. 2010; Pragasan 2015; Scott et al. 2004; Wei et al. 2013). However, even standard allometric equations which are reasonably accurate to predict the biomass mostly incorporate easily measured parameter like DBH and height only

(Baral, Malla, and Ranabhat 2010; Cole and Ewel 2006; Karki et al. 2016; Ni-Meister et al. 2010; Pandey and Bhusal 2016; Parrotta, Wildburger, and Mansourian 2012; Ribeiro et al. 2015; Shah and Acharya 2010; Sharma and Kakchapati 2018). A study by Pandey, Cockfield, and Maraseni (2014) for REDD + piloting project that included crown cover strata (sparse $<70 \%$ crown cover and dense $\geq 70 \%$ crown cover) shows that there is a significant difference in stand-level carbon stock estimation by canopy coverage. Moreover, results-based payment in REDD + program also requires accurate estimation of carbon stock by forest types, composition, management modalities, crown cover and geographic locations (Pandey, Cockfield, and Maraseni 2014; Sharma and Kakchapati 2018). In such case, incorporating crown cover for stratification with remote sensing techniques while conducting forest measurement or developing allometric equation not only reduces the cost of forest inventory or estimate more accurate values but also improves the reliability of the equation.

Various studies have been conducted to develop biomass equation for specific species and groups of species. Several biomass-prediction equations have been developed for tropical plant species like: (1) Cole and Ewel (2006) for Cedrela odorata, Cordia alliodora, Hyeronima alchorneoides, and Euterpe oleracea; (2) Ounban et al. (2016) for Tectona grandis and Ecaluptus camaldulenis; (3) Mohd Zaki et al. (2016) for Dipterocarp species of Malaysia; and (4) Chave et al. (2005) for tropical forest. Currently, in Nepal, estimate of biomass depends on biomass prediction and allocation system developed by Sharma and Pukkala (1990) or Chave et al. (2005). Even though Joshi et al. (2015) developed general allometric equation for Paulownia tementosa, Shrestha et al. (2018) developed local volume table for Terai species and Bhandari and Neupane (2014) for Castanopsis indica, there is no specific allometric equation for predicting carbon stock by variable like crown cover even for species popular species Sal (Shorea robusta). According to Department of Forest Research and Survey (DFRS) (2015) Sal forest alone accounts for $15.27 \%$ of total forest area. In addition, the study also found that another $24.61 \%$ of forest area exists in the form of tropical mixed hardwood forest resulting in Sal representing total of $26-28 \%$ of stem volume in Nepal. So, developing regression equation for estimation of carbon stock for natural Sal forest by crown cover will not only estimate the accurate carbon stock but also helps to determine the level of thinning in forest management. Therefore, this study aimed to estimate carbon stock by crown 
cover class and develop regression models to estimate carbon stock for various crown cover measuring $\mathrm{DBH}$ and total height of tree at field level and classifying crown cover with remote sensing.

\section{Results}

\section{Crown cover classification}

Division of forest into four different crown cover classes shows that majority of forest areas fall under crown cover class 50-75\% whereas only around 50 ha of forest was covered by crown cover class $<25 \%$ (Table 1). Cohen's kappa coefficient calculated from the error matrix shows that the overall accuracy of the classification was more than $85 \%$.

Table 1: Area coverage by crown cover class

\begin{tabular}{|l|c|}
\hline Crown cover class & Area (Ha) \\
\hline$<25 \%$ & 49.60 \\
\hline $25-50 \%$ & 120.65 \\
\hline $50-75 \%$ & 380.19 \\
\hline$>75 \%$ & 122.28 \\
\hline Total & 672.72 \\
\hline
\end{tabular}

[Figure 1]

\section{Carbon stock}

There was a fluctuation in the number of stems with increase in crown cover, where on an average 297 stems per hectare were recorded in study area with highest number of stems in crown cover class $>75 \%$. Similarly, per tree growing stock and carbon stock was highest for crown cover class $>75 \%$ and lowest for 25-25 \% crown cover class despite having the second largest number of stems per ha in the class. Growing stock (GS), above ground biomass (AGB), total biomass (TB) and carbon stock (CS) was observed to have increased with increase in crown coverage. Table 2 shows that estimated variables by crown cover class and weighted average for the whole area.

Table 2: Number of stems, growing stock and biomass by crown cover

\begin{tabular}{|l|l|l|l|l|l|}
\hline \multirow{2}{*}{ Variable } & \multicolumn{3}{|c|}{ Crown cover class (average) } & \multirow{2}{*}{ Average (weighted) } \\
\cline { 2 - 5 } & $<25 \%$ & $25-50 \%$ & $50-75 \%$ & $>75 \%$ & \\
\hline No. of stands /ha & 161 & 345 & 288 & 375 & 297 \\
\hline Growing stock $\left(\mathrm{m}^{3} / \mathrm{ha}\right)$ & 44.42 & 91.07 & 100.47 & 137.99 & 94.80 \\
\hline Per tree GS $\left(\mathrm{m}^{3} / \mathrm{ha}\right)$ & 0.28 & 0.26 & 0.35 & 0.37 & 0.31 \\
\hline AGB (ton/ha) & 48.72 & 100.52 & 114.06 & 159.28 & 107.11 \\
\hline Total biomass (ton/ha) & 58.46 & 120.62 & 136.87 & 191.13 & 128.53 \\
\hline Total CS (ton/ha) & $\mathbf{2 7 . 4 7}$ & $\mathbf{5 6 . 6 9}$ & $\mathbf{6 4 . 3 3}$ & $\mathbf{8 9 . 8 3}$ & $\mathbf{6 0 . 4 1}$ \\
\hline Per tree CS (ton/ha) & $\mathbf{0 . 1 7}$ & $\mathbf{0 . 1 6}$ & $\mathbf{0 . 2 2}$ & $\mathbf{0 . 2 4}$ & $\mathbf{0 . 2 0}$ \\
\hline
\end{tabular}

Four estimated variables (GS, AGB, TB, CS) were plotted against crown cover in Boxwhisker plot for displaying the variation in data by crown cover class. It shows that the variability in data was seen more in crown cover class $>75 \%$ for all four estimated variables and less in crown cover class $<25 \%$.

[Figure 2]

One-way ANOVA showed a significant difference in total carbon stock with crown cover class at $95 \%$ confidence interval. TukeyHSD, test to explore the significance between different pairs of crown cover, showed that three pairs of crown cover category $(<25$ to 25- 
$50,<25$ to $50-75$ and $25-50$ to $>100$ ) significantly differ at $95 \%$ confidence interval (Table 3 ) whereas $<25$ to $>100$ pairs were significantly different at $99.9 \%$ confidence interval.

Table 3: Pair-wise comparison of carbon stock by crown cover

\begin{tabular}{|l|l|l|l|l|l|}
\hline Crown cover Percentage & Diff & Lower & Upper & P-value & Significance level \\
\hline $0-25$ to $25-50$ & 28.96 & 1.65 & 56.27 & 0.033 & $*$ \\
\hline $0-25$ to $50-75$ & 36.53 & 9.22 & 63.84 & 0.004 & $*$ \\
\hline $0-25$ to $75-100$ & 61.81 & 33.89 & 89.72 & 0.000 & $* * *$ \\
\hline $25-50$ to $50-75$ & 7.57 & -18.34 & 33.48 & 0.860 & \\
\hline $25-50$ to $75-100$ & 32.85 & 6.29 & 59.39 & 0.009 & $*$ \\
\hline $50-75$ to $75-100$ & 25.28 & -1.27 & 51.83 & 0.070 & \\
\hline
\end{tabular}

Confidence level ***’ 99.9\% ‘**’ 99\% ‘*’ 95\%

\subsection{Model for Carbon Stock Estimation}

Regression equation to model each crown cover class was developed from DBH and height as independent variables where crown cover was used as a categorical variable. Models were selected after the intercept of $\mathrm{DBH}$ and height were positive, adjusted $\mathrm{R}^{2}$ value was above 0.99 and residual areas normally distributed and homogeneous.

Fitted model for estimating carbon stock where DBH and Height are independent variables with base of natural logarithm is given as:

[Due to technical limitations, the formula could not be displayed here. Please see the supplementary files section to access the formula.]

Where, CS is in $\mathrm{kg} /$ tree, $\mathrm{DBH}$ in $\mathrm{cm}$ and Height in $\mathrm{m}$.

Table 4: Estimated intercepts of DBH, Height for estimating CS by different CC

\begin{tabular}{|l|l|l|l|l|c|}
\hline CC \% & Intercept (SE) (c) & $\begin{array}{c}\text { DBH (SE) } \\
(\mathbf{a})\end{array}$ & $\begin{array}{c}\text { Height (SE) } \\
(\mathbf{b})\end{array}$ & $\mathbf{R}^{2}$ & p-value \\
\hline $0-25$ & $-3.22(0.062)$ & $1.05(0.01)$ & $0.72(0.035)$ & 0.9984 & $<2.2 \mathrm{e}-16$ \\
\hline $25-50$ & $-3.31(0.023)$ & $1.04(0.005)$ & $0.76(0.014)$ & 0.9986 & $<2.2 \mathrm{e}-16$ \\
\hline $50-75$ & $-3.32(0.034)$ & $1.04(0.006)$ & $0.77(0.019)$ & 0.9986 & $<2.2 \mathrm{e}-16$ \\
\hline $75-100$ & $-3.42(0.03)$ & $1.01(0.005)$ & $0.86(0.016)$ & 0.9987 & $<2.2 \mathrm{e}-16$ \\
\hline
\end{tabular}

Similar biomass model was fitted for four different crown cover classes where all models were statistically different with decreasing order of intercept. The fitted models have adjusted $\mathrm{R}^{2}$ value of more than 0.99 (Table 3 ) and residuals are normally distributed (Figure 5). Selected models were plotted with natural logarithm of DBH and height along with estimated carbon stock in 3d scatter diagram as shown in Figure 5.

[Figure 3]

\section{Discussion}

We found that linear model with natural logarithm of $\mathrm{DBH}^{2}$ and height is best fit to predict carbon stock of Sal forest of Chure region where average carbon stock density was found to be 60 ton/ ha with highest carbon stock (89.83 ton/ha) for crown cover class $>75 \%$ and lowest (27.47 ton/ha) for $<25 \%$ crown cover strata. Carbon stock density largely varied by crown cover where per tree carbon stock was highest $(0.24)$ for $>75 \%$ crown cover class and lowest $(0.16)$ for $<25 \%$. Similarly, the number of stands were fluctuating with increase in crown cover class due to the presence of higher number of pole sized stems in 25-50 \% crown cover class. 
Master plan for Chure conservation and management of Nepal government shows that hill Sal forest is a dominant forest system in Chure region of Nepal. In this area, hill Sal forest is associated with species like Botdhayaro (Lagerstroemia parviflora), Saj (Terminalia tomentosa), Bajhi (Anogeissus latifolia) (Pandey, Maraseni, and Cockfield 2014). Forest area under this region is environmentally protected, as specially designed protection system to control soil erosion since 2010, where maintaining healthy crown coverage is a major goal (GoN/PCTMCDB 2016; Singh 2012). Mapping of crown cover in the study area shows that more than $70 \%$ of the total forest area has crown cover of at least $50 \%$ where number of stands in different crown cover class fluctuated. This finding is similar to a pilot study conducted for REDD+ activities in CF which also estimated large area under dense ( $>70 \%$ canopy cover) canopy class (7436 ha) compared to sparse ( $<70 \%$ canopy class) canopy forest (2829.5 ha) (Pandey, Cockfield, and Maraseni 2014). Furthermore, Department of Forest Resources Survey (DFRS) on 2015 estimated that there were only 183.16 stands/ha of Sal in average in Terai region compared to 297 stands/ha in this study. Major reason behind estimating higher number of stands in this study is that forest in this area is newly developed and thinning activities have not been performed and a large quantity of stands of pole size (i.e., DBH $<30 \mathrm{~cm}$ ) were recorded.

While comparing the average carbon stock to other closely related studies (Table 4), it was found that carbon stock density varies for Sal forest. The extent of variation depended on the pools of carbon included in studies where inclusion of soil carbon resulted in higher carbon stock (Table 5). The major reason behind estimating lower carbon stock in this study include only accounting for carbon stock of tree and pole (DBH $>7 \mathrm{~cm}$ ) (including roots) as well as the presence of large number of small aged individual stands in the study area. The results are consistent with Sharma and Kakchapati's (2018) conclusion that stem volume, $\mathrm{DBH}$, and the number of stems per plot have positive association with carbon stock of the Sal forest in Chure region of Nepal.

Table 5: Carbon stock reported by earlier studies

\begin{tabular}{|c|c|c|c|}
\hline Area and forest types & $\begin{array}{l}\text { Carbon } \\
\text { ton/ha }\end{array}$ & Pools included & Reported by \\
\hline Chure region Sal forest & 76.76 & $\begin{array}{l}\text { AG, BG (litter, debris and soil } \\
\text { component) }\end{array}$ & $\begin{array}{l}\text { Sharma and Kakchyapati } \\
\text { (2018) }\end{array}$ \\
\hline Terai Sal forest & 479.29 & AG, BG and soil & $\begin{array}{l}\text { Pandey and Bhusal } \\
\text { (2016) }\end{array}$ \\
\hline Terai Sal forest of Nepal & 123.14 & $\mathrm{AG}$ & FAO (2010) \\
\hline Chure Forest area & 116.94 & $\begin{array}{l}\text { AG, BG (litter, debris } \\
\text { including) }\end{array}$ & DFRS (2014) \\
\hline Sal forest (Chitwan) & $\begin{array}{c}106.69 \text { (in } \\
2010 \text { ) } \\
115.04 \text { (in } \\
2011 \text { ) } \\
117.82 \text { (in } \\
2013 \text { ) } \\
\end{array}$ & AG including litter & $\begin{array}{l}\text { Pandey, Marasaini and } \\
\text { Cockfild (2014) }\end{array}$ \\
\hline $\begin{array}{l}\text { Shorea robusta and Accacia species } \\
\text { forest of Bihar, India }\end{array}$ & 53.75 & AG (litter excluded) & $\begin{array}{l}\text { Kaul, Dadhwal, and } \\
\text { Mohren (2009) }\end{array}$ \\
\hline $\begin{array}{l}\text { Average carbon stock for } 18 \\
\text { countries including Nepal }\end{array}$ & 85.6 & AG (Litter excluded) & FAO (2010) \\
\hline Chure Sal forest & 60.41 & $\begin{array}{l}\text { AG and BG (with } \\
\text { consideration of crown cover) }\end{array}$ & This study \\
\hline
\end{tabular}


Carbon stock varied with crown coverage with highest carbon stock recorded in $>75 \%$ crown cover class where there was significant difference in tree carbon stock by crown coverage. This is analogous with other studies which concluded that total forest carbon storage varies with increased stand age and number of stands along with crown coverage (Luyssaert et al. 2008; Ounban, Puangchit, and Diloksumpun 2016; Pandey et al. 2019; Scott et al. 2004; Shah and Acharya 2010; Wei et al. 2013). Pandey, Cockfield and Marasaini (2014) reported that 115.40 (t/ha) and 70.0 (t/ha) in 2010, 124.80 (t/ha) and 74.53 (t/ha) in 2011 and 128.22 (t/ha) and 74.60 (t/ha) carbon stock in dense and sparse canopy cover strata, whereas Pandey et al. (2014) estimated 129.9 (t/ha) and 89.2 (t/ha) for dense and sparse strata for tropical Sal forest of Chitwan district where biomass of seedling sapling, dry fallen litter and twigs were also included in the study. Similarly, Karki et al. (2016) estimated 271.50 (ton C / ha) for dense forest strata and 248.72 (ton C/ ha) for sparse strata for mix forest in Lalitpur. However, carbon stock density in each stratum was lower than other studies which is mainly due to young aged forest and presence of higher number of poles.

[Figure 4]

Equations available for predicting biomass of a single tree mostly use a function of easily measured variable like DBH and tree height and are usually developed for particular species or species group. So, we regress the carbon stock by crown cover from predictors (DBH and height) to develop allometric equation to estimate carbon stock. This is consistent with the previous studies in which $\mathrm{DBH}$ and Height were used as predictor variables for the estimation of the total amount of carbon and biomass (Joshi et al. 2015; Karki et al. 2016; Luyssaert et al. 2008; Ribeiro et al. 2015). However, allometric equations developed for predicting biomass or carbon vary widely, but the easiest and most commonly used is a linear model in the form of $\mathrm{y}=\mathrm{a}+\mathrm{bX}$ where $\mathrm{x}$ is $\mathrm{DBH}$ and $\mathrm{a}$ and $\mathrm{b}$ are slopes. Unlike other studies (Cole and Ewel 2006; Joshi et al. 2015; Ribeiro et al. 2015; Shah and Acharya 2010; Tashi et al. 2017; Mohd Zaki et al. 2016) where models are mostly developed from directly measured variable like DBH and/or Height, with categorization into different crown cover classes, linear model with natural logarithm of $\mathrm{DBH}^{2}$ and height was best fitted for Chure Sal forest. These regression equations are highly precise (adjusted $\mathrm{R}^{2}>0.99$, residuals are normally distributed as seen in Figure 4). Carbon stock estimation by application of remote sensing for stratification (Asner 2009) of particularly dynamic crown coverage results in precise estimation of carbon stock.

\section{Conclusions}

There is a relation between total biomass carbon and degree of crown coverage for Sal forest. The application of stratified sampling for developing model for measurement of carbon stock by crown cover class is more precise and accurate which should be used for estimation of carbon stock of Sal forest. Therefore, we strongly recommend the inclusion of crown cover as strata for better estimation of biomass and carbon stock. This equation will help managers for better management of forest for maximum carbon sequestration and accurate and cost-effective methods to estimate carbon stock. Developing such models for other forest type can be linked with result-based payment like REDD + which requires accurate and precise measurement of sequestrated carbon.

\section{Methods}

\section{Study Area}


The study was conducted in Hetauda sub-metropolitan city ward no 14, entirely located in Chure region of Nepal (Figure 1). This region is very fragile and gently sloped. Out of total 244,967 ha of land, more than $48 \%$ of land falls under Chure region in Makwanpur district, where Hill Sal forest covers around 72\% of total forest area (DFO 2019; GoN/PCTMCDB 2016). District sector plan of Makwanpur shows that forest, barren land, agriculture land, buildup area and shrubland are major land use types in the district. Similarly, the study area is dominated by forest (672.72 ha out of 1637.13 ha) followed by cultivated/buildup land (526.77 ha). The study area is dominated by Sal forest where trees of all ages were recorded with majority in pole stages $(7 \mathrm{~cm}$ to $30 \mathrm{~cm}$ ).

[Figure 5]

\section{Crown cover classification}

Landsat 16 image having 20 X 20 grid with Path 141* and row 041* was downloaded from a free source and clipped with study area. Four crown cover classes viz < 25\%, 25 to 50\%, 50 to $75 \%$ and $>75 \%$ were prepared for study area with tending sample and ground truth with the help of a map making tool (ARCGIS 10.2.2). For the whole procedure, tending sample of 10n (where $\mathrm{n}$ is the number of classes) and ground truth sample 10n were taken. Further, supervised classification was carried out for the tending sample. Similarly, accuracy assessment was performed on classified images to determine accomplishment of the classification process where Cohen's kappa coefficient was calculated from the error matrix to assess the accuracy assessment of the image.

\section{Data collection and analysis}

Using Stratified random sampling, 160 plots were randomly established representing the whole forest area with sampling intensity of at least $1 \%$ for all crown cover class (Figure 2). Sample plots were randomly selected after stratification by crown cover class in each stratum and field measurements were only confined to plots in which all stands (poles/trees) were Sal. Measurement of DBH and height was carried out for all trees more than $7 \mathrm{~cm} \mathrm{DBH}$. Even though there were 40 plots (pre-located) in each stratum only 82 plots in total were valid for measurement (18, 22, 22 and 20 for crown cover strata $<25 \%$, $25-50 \%, 50-75 \%$ and $>75 \%$ respectively) after omitting plots where other species were present. From the central point of the sample plot, a concentric plot with radius $5.78 \mathrm{~m}$ (i.e., area of $100 \mathrm{~m}^{2}$ ) and $12.61 \mathrm{~m}\left(500 \mathrm{~m}^{2}\right)$ were established to measure poles (DBH $7 \mathrm{~cm}$ to $<30 \mathrm{~cm}$ ) and trees $(\mathrm{DBH}>30 \mathrm{~cm})$, respectively, as suggested by Community Forestry Guideline (1996) (Ranabhat, Awasthi, and Malla 2008). DBH of each tree was measured using a diameter tape at $1.3 \mathrm{~m}$ from ground whereas total tree height was measured using Vertex.

[Figure 6]

\section{Analysis}

Based on the field measurement of $\mathrm{DBH}$ and height of standing tree, volume of standing tree was calculated using formula (Eq. i) developed by Sharma and Pukkala (1990) for Sal forest where biomass of individual tree was calculated by multiplying the volume of individual tree by wood specific gravity of Sal $\left(880 \mathrm{~kg} / \mathrm{m}^{3}\right)$.

$$
\ln (\mathrm{v})=-2.4554+1.9026 \ln (\mathrm{d})+0.8352 \ln (\mathrm{h}) \ldots \ldots \ldots . . \text { Eq. (i) }
$$

Where, $\mathrm{ln}=$ natural logarithm, $\mathrm{v}=$ volume over bark $\left(\mathrm{m}^{3}\right), \mathrm{d}=\mathrm{DBH}(\mathrm{cm}), \mathrm{h}=$ total height of tree $(\mathrm{m})$.

Branch and foliage biomass were calculated by using the ratio of converting branch and foliage biomass into tree biomass as given by Sharma and Pukkala (1990) for Sal species. Similarly, root biomass was estimated by multiplying above ground biomass by 0.20 as suggested by the carbon inventory guidelines of Nepal government (DFRS/MoFSC 2015; Pandey and Bhusal 2016; Subedi et al. 2016). Ratio given by IPCC (2014) for estimating carbon stock for individual tree i.e. $47 \%$ of total biomass was used to calculate the total 
carbon stock of each tree (Pandey and Bhusal 2016). Furthermore, one-way ANOVA was used to test the significance difference in total carbon stock for crown cover classes, where TukeyHSD was conducted to identify significantly different pair of crown cover at 95\% confidence interval. Model for predicting carbon stock for each crown cover class was developed using $\mathrm{DBH}$ and total tree height where intercept for $\mathrm{DBH}$ and height was estimated.

The generalized allometric equation between the component carbon stock and independent variables $\mathrm{DBH}^{2}$ and Height was developed using simple linear regression. The models were fitted by ordinary linear model with the $\mathrm{lm}$ function in $\mathrm{R}$ ( $\mathrm{R}$ Core team, 2018). Before regression, a logarithmic transformation of both $\mathrm{DBH}$ and Height was applied to correct heterogenous variation of the regression (Fei et al. 2017; Wang et al. 2014). The linear regression equation was fitted at $99 \%$ confidence interval. The fitted model was evaluated by value of Adjusted $\mathrm{R}^{2}$ and distribution of error by normal Q-Q plot in $\mathrm{R}$. The adjusted $\mathrm{R}^{2}$ is adopted when linear models are localized (Pérez-Cruzado et al. 2015).

\section{Abbreviations}

AGB- Above Ground Biomass;

BG- Below Ground

CF- Community Forest

CS- Carbon Stock

c/ha- carbon stock (ton) per hectare

DBH-Diameter at Breast Height

DFRS- Department of Forest Research and Survey

FAO- Food and Agriculture Organization

GON- Government of Nepal

PCTMCDB- President Chure Terai Madesh Conservation Development Board

SE- Standard Error

TB- Total Biomass

t/ha- Ton per hectare

\section{Declarations}

Ethics approval and consent to participate 
Not applicable

\section{Consent for publication}

Not applicable

\section{Availability of data and material}

The data set during and/or analyzed during the current study available from the corresponding author on request.

\section{Competing interest}

The author declares that no competing interest exists.

\section{Finding}

The author received no specific funding for this work.

\section{Authors' Contribution}

Mr. Prashant Paudel- Research design, data collection, analysis and writing

Mr. Rupesh Kalakheti- Data collection, data entry and data analysis

Prof. Tek Maraseni (PhD)- guidance, supervision and editing

\section{Acknowledgements}

Special regards to Prof. Basudev Pokhrel for this quick observation and guidance. We would also like to thank Mr. Binay Mishra, Mr. Bimal KC, Mr. Pratik Sadaula and Mr. Basant Lamsal for their help in data collection.

\section{References}


Asner, Gregory P. 2009. "Tropical Forest Carbon Assessment: Integrating Satellite and Airborne Mapping Approaches." Environmental Research Letters 4(3).

Baral, SK, R Malla, and S Ranabhat. 2010. "Above-Ground Carbon Stock Assessment in Different Forest Types of Nepal." Banko Janakari 19(2): 10-14.

Bhandari, S. K., and H. Neupane. 2014. "Allometric Equations for Estimating the Above-Ground Biomass of Castanopsis Indica at Juvenile Stage." Banko Janakari 24(1): 14-22.

Chave, J. et al. 2005. "Tree Allometry and Improved Estimation of Carbon Stocks and Balance in Tropical Forests." Oecologia 145(1): 87-99.

Cole, Thomas G., and John J. Ewel. 2006. "Allometric Equations for Four Valuable Tropical Tree Species." Forest Ecology and Management 229(1-3): 351-60.

DFO. 2019. Division Forest Office Makwanpurs' 10 Years Forest Development Strategic Plan. Hetauda.

DFRS/MoFSC. 2015. STATE of NEPAL 'S FORESTS. Kathmandu.

DFRS. 2014. Churia Forests of Nepal Churia Forests of Nepal (2011-2013). Kathmandu.

Dixon, Author R K et al. 1994. "Carbon Pools and Flux of Global Forest Ecosystems Published by: American Association for the Advancement of Science Stable URL:

Http://Www.Jstor.Org/Stable/2882371." Advancement Of Science 263(5144): 185-90.

FAO. 2010. Country Report, Nepal Global Forest Resources Assessment 2010. Rome.

Fei, Ran et al. 2017. "Allometric Equations of Select Tree Species of the Tibetan Plateau, China." Journal of Mountain Science 14(9): 1889-1902.

GoN/PCTMCDB. 2016. President Chure-Tarai Madhesh Conservation and Management Master Plan. Kathmandu. http://chureboard.gov.np/en/wp-content/uploads/sites/2/2017/07/MasterPlan_Churia_English_final_24th_Shrawan_2074.pdf.

IPCC. 2014. Ipcc Climate Change 2014 Synthesis Report Summary Chapter for Policymakers. https://www.ipcc.ch/site/assets/uploads/2018/02/AR5_SYR_FINAL_SPM.pdf.

Jina, B. S., Pankaj Sah, M. D. Bhatt, and Y. S. Rawat. 2009. "Estimating Carbon Sequestration Rates and Total Carbon Stockpile in Degraded and Non-Degraded Sites of Oak and Pine Forest of Kumaun Central Himalaya." Ecoprint: An International Journal of Ecology 15: 75-81.

Joshi, N R et al. 2015. 10 Development of allometric equations for P. tomentosa (Thunb.) to estimate biomass and carbon stocks - an assessment conducted in the ICIMOD knowledge park, Godavari, Nepal. ICIMOD Working Paper 2015/10. Kathmandu: ICIMOD Development of Allometric Equations for 
Paulownia Tomentosa (Thunb.) to Estimate Biomass and Carbon Stocks: An Assessment from the ICIMOD Knowledge Park, Godavari, Nepal. http://lib.icimod.org/record/31838.

Karki, S et al. 2016. ICIMOD Assessment of Forest Carbon Stock and Carbon Sequestration Rates at the ICIMOD Knowledge Park in Godavari, Nepal. Kathmandu. http://lib.icimod.org/record/32299.

Kaul, M., V. K. Dadhwal, and G. M.J. Mohren. 2009. "Land Use Change and Net C Flux in Indian Forests." Forest Ecology and Management 258(2): 100-108.

Luyssaert, Sebastiaan et al. 2008. "Old-Growth Forests as Global Carbon Sinks." Nature 455(7210): 21315.

MacDicken, K G. 1997. A Guide to Monitoring Carbon Storage in Forestry and Agroforestry Projects.

Maraseni, T. N., and S. S. Pandey. 2014. "Can Vegetation Types Work as an Indicator of Soil Organic Carbon? An Insight from Native Vegetations in Nepal." Ecological Indicators 46: 315-22.

http://dx.doi.org/10.1016/j.ecolind.2014.06.038.

Mohd Zaki, Nurul Ain, Zulkiflee Abd Latif, Mohd Nazip Suratman, and Mohd Zainee Zainal. 2016. "Aboveground Biomass and Carbon Stocks Modelling Using Non-Linear Regression Model." In IOP Conference Series: Earth and Environmental Science, IOP Publishing.

Ni-Meister, Wenge et al. 2010. "Assessing General Relationships between Aboveground Biomass and Vegetation Structure Parameters for Improved Carbon Estimate from Lidar Remote Sensing." Journal of Geophysical Research: Biogeosciences 115(G00E11).

Ounban, Waraporn, Ladawan Puangchit, and Sapit Diloksumpun. 2016. "Development of General Biomass Allometric Equations for Tectona Grandis Linn.f. and Eucalyptus Camaldulensis Dehnh. Plantations in Thailand." Agriculture and Natural Resources 50(1): 48-53.

http://dx.doi.org/10.1016/j.anres.2015.08.001.

Pandey, H. P., P. Pandey, S. Pokhrel, and R. A. Mandal. 2019. "Relationship between Soil Properties and Forests Carbon: Case of Three Community Forests from Far Western Nepal." Banko Janakari 29(1): 4352.

Pandey, H P, and M Bhusal. 2016. "A Comparative Study on Carbon Stock in Sal (." Banko Janakari 26(1): 24-31.

Pandey, Shiva Shankar, Geoff Cockfield, and Tek Narayan Maraseni. 2014. "Dynamics of Carbon and Biodiversity under REDD+ Regime: A Case from Nepal." Environmental Science and Policy 38(Cop 13): 272-81. http://dx.doi.org/10.1016/j.envsci.2014.01.005.

Pandey, Shiva Shankar, Tek Narayan Maraseni, Geoff Cockfield, and Karin Gerhard. 2014. "Tree Species Diversity in Community Managed and National Park Forests in the Mid-Hills of Central Nepal." Journal of 
Sustainable Forestry 33(8): 796-813.

Parrotta, John A, Christoph Wildburger, and Stephanie Mansourian. 2012. 31 Understanding

Relationships between Biodiversity, Carbon, Forests and People: The Key to Achieving REDD+ Objectives.

Pérez-Cruzado, César et al. 2015. "On the Site-Level Suitability of Biomass Models." Environmental Modelling and Software 73: 14-26.

Pragasan L, Arul. 2015. "Tree Carbon Stock Assessment from the Tropical Forests of Bodamalai Hills Located In India." Journal of Earth Science \& Climatic Change 06(10).

Le Quéré, Corinne et al. 2009. "Trends in the Sources and Sinks of Carbon Dioxide." Nature Geoscience 2(12): 831-36.

R Core Team, 2018. "R: a Language ans Environment for Stastical COmpution. R Foundation for Statistical Computing.

Ranabhat, S, KD Awasthi, and R Malla. 2008. "Carbon Sequestration Potential of Alnus Nepalensis in the Mid Hill of Nepal: A Case Study from Kaski District." Banko Janakari 18(2): 3-9.

Ribeiro, Sabina Cerruto et al. 2015. "Abovegroung and Belowground Biomass and Carbon Estimates for Clonal Ecalyptus Trees in Southeast Brazil." Revista Árvore, Viçosa-MG 39(3): 353-63.

Scott, Neal A. et al. 2004. "Changes in Carbon Storage and Net Carbon Exchange One Year after an Initial Shelterwood Harvest at Howland Forest, ME." Environmental Management 33(SUPPL. 1): 9-22.

Shah, S. K., and H. Acharya. 2010. "Modelling the Relationship between Canopy Projection Area and Above-Ground Carbon Stock of Intermingled Canopy Trees Using High-Resolution Satellite Imagery." Banko Janakari 23(2): 20-29.

Sharma, E. R. \& Pukkala, T. 1990. Volume Equations and Biomass Prediction of Forest Trees of Nepal. Kathmandu.

Sharma, Ira, and Sampurna Kakchapati. 2018. "Linear Regression Model to Identify the Factors Associated with Carbon Stock in Chure Forest of Nepal." Hindawi Scientifica 2018.

Shrestha, H. L. et al. 2018. "Developing Local Volume Tables for Three Important Tree Species in Nawalparasi and Kapilvastu Districts." Banko Janakari Sp. Issue(4): 84-91.

Singh, Bijay Kumar. 2012. Doctor of Philosophy in Forestry "Social Inclusion/ Exclusion of River- Affected Downstream People in Conservation and Management of Fragile Churia Hill: Linking Upstream and Downstream from the Perspective of Environmental Servies $\square$. ." Tribhuvan University.

Subedi, B.P., K. Gauli, N.R. Joshi, A. Pandey, S. Charmakar, A. Poudel, M.R.S. Murthy, H. Glani and S.C. Khanal. 2016. Forest Carbon Assessment in Chitwan-Annapurna Landscape. Study Report. WWF Nepal, 
Hariyo Ban Program, Baluwatar, Kathmandu, Nepal. Kathmandu. www.wwfnepal.org/hariyobanprogram/.

Tashi, Sonam, Claudia Keitel, Balwant Singh, and Mark Adams. 2017. "Allometric Equations for Biomass and Carbon Stocks of Forests along an Altitudinal Gradient in the Eastern Himalayas." Forestry: An International K=Journal of Forest Research 90(3): 445-54.

Wang, Genxu et al. 2014. "Variations in the Live Biomass and Carbon Pools of Abies Georgei along an Elevation Gradient on the Tibetan Plateau, China." Forest Ecology and Management 329: 255-63. http://dx.doi.org/10.1016/j.foreco.2014.06.023.

Wei, Yawei et al. 2013. "Variation in Carbon Storage and Its Distribution by Stand Age and Forest Type in Boreal and Temperate Forests in Northeastern China." PLOS ONE 8(8): 1-9.

Yohannes, Hamere, and Teshome Soromessa. 2015. "Carbon Stock Analysis along Slope and Slope Aspect Gradient in Gedo Forest: Implications for Climate Change Mitigation." Journal of Earth Science \& Climatic Change 06(09): 6-11.

\section{Figures}




\section{CROWN COVER MAP}

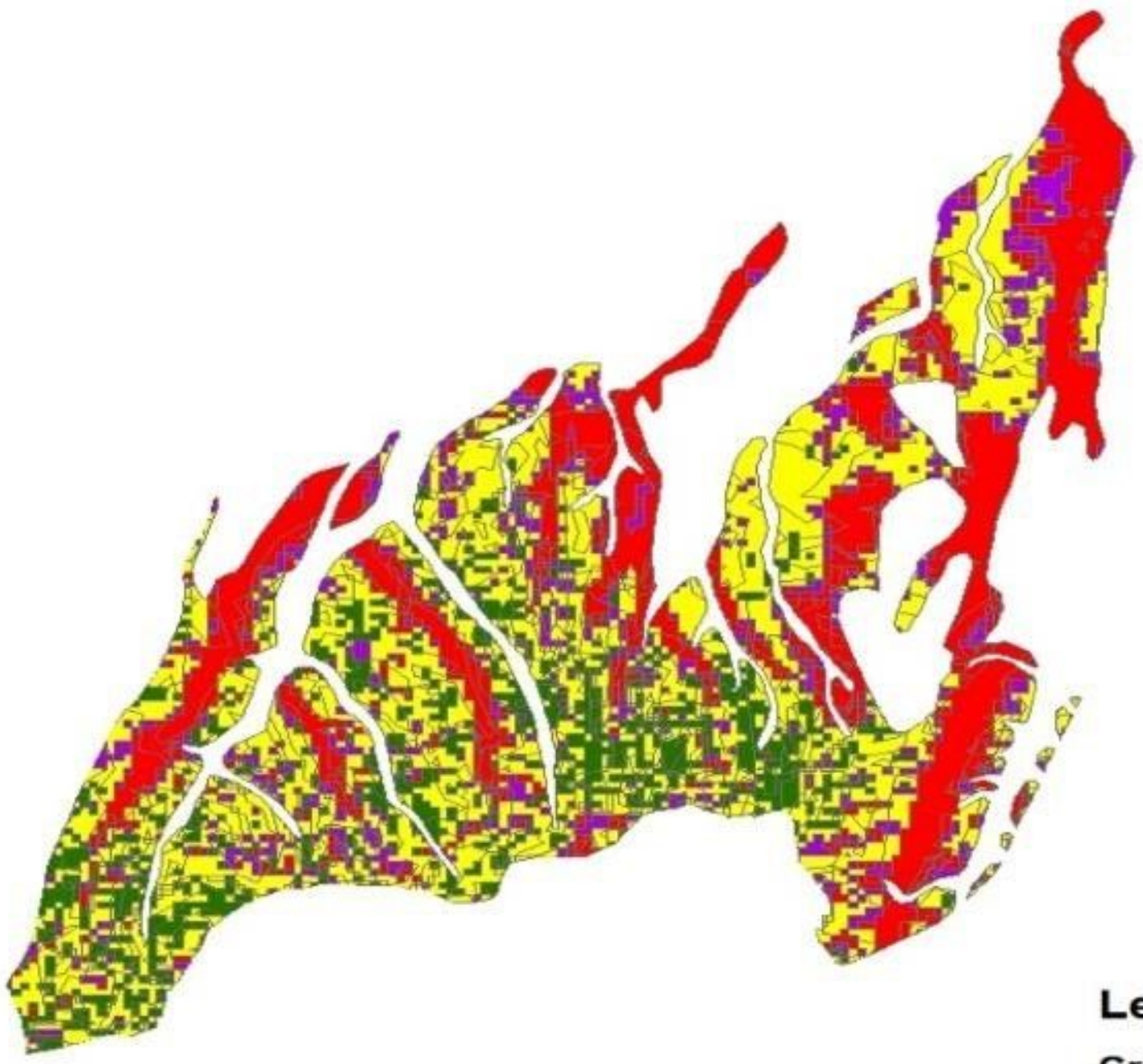

Legend Crown Cover
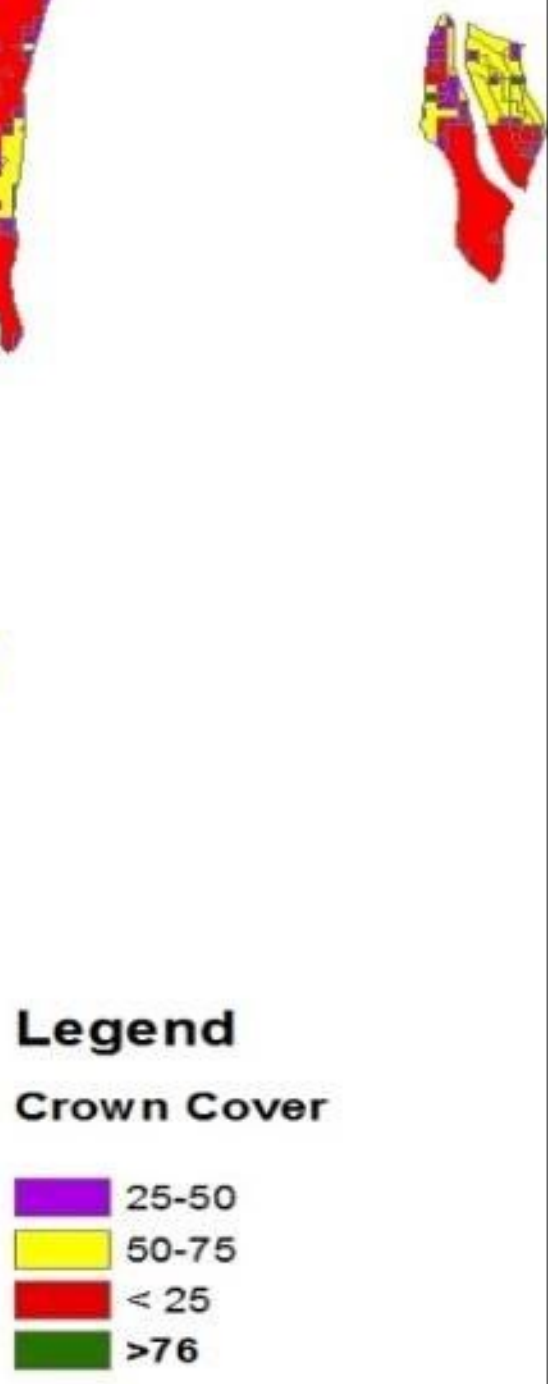

Figure 1

Crown cover map of study area 

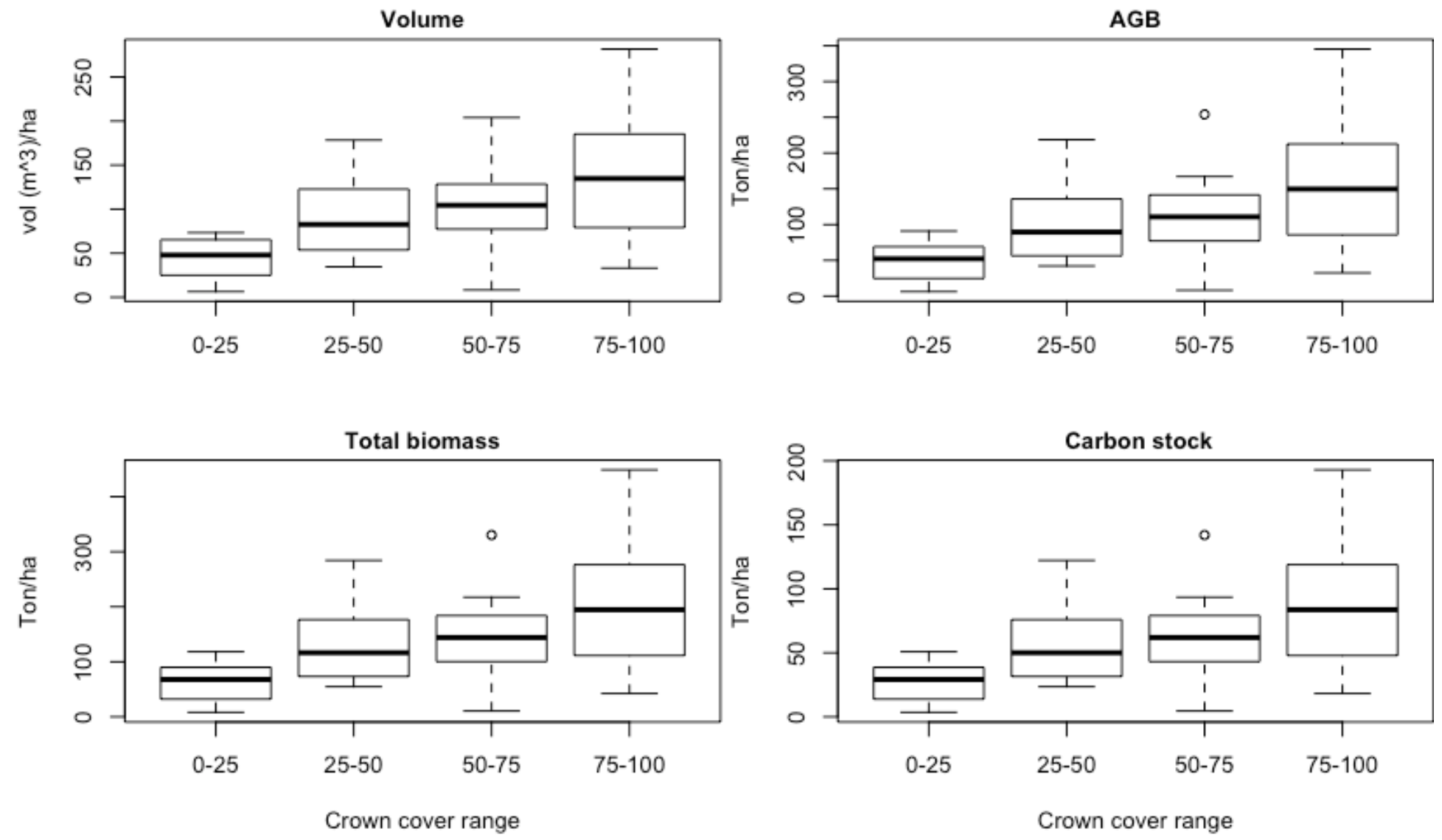

Figure 2

Box-whisker plot of total Growing stock, Above-ground biomass, Total biomass and total carbon stack by crown cover class 
3d Scatter diagram for $<25 \%$ CC

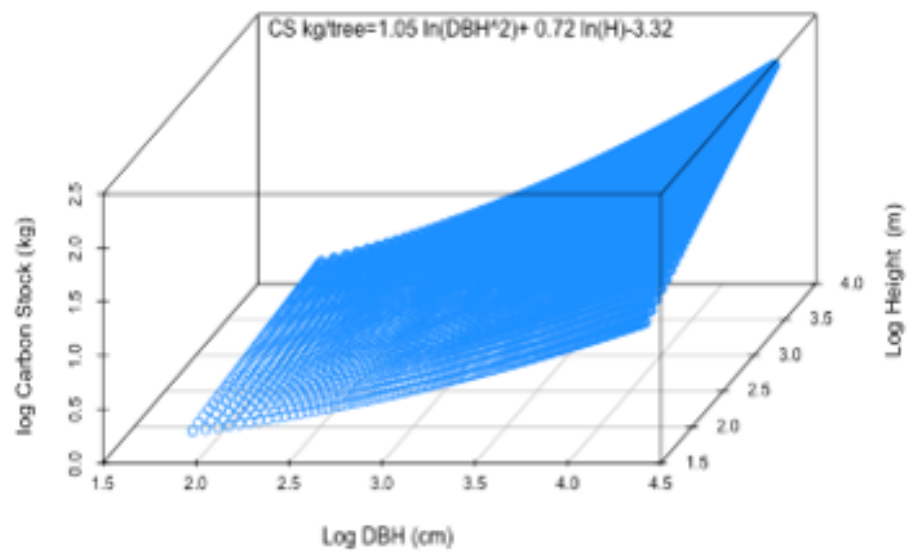

3d Scatter diagram for $50-75 \%$ CC

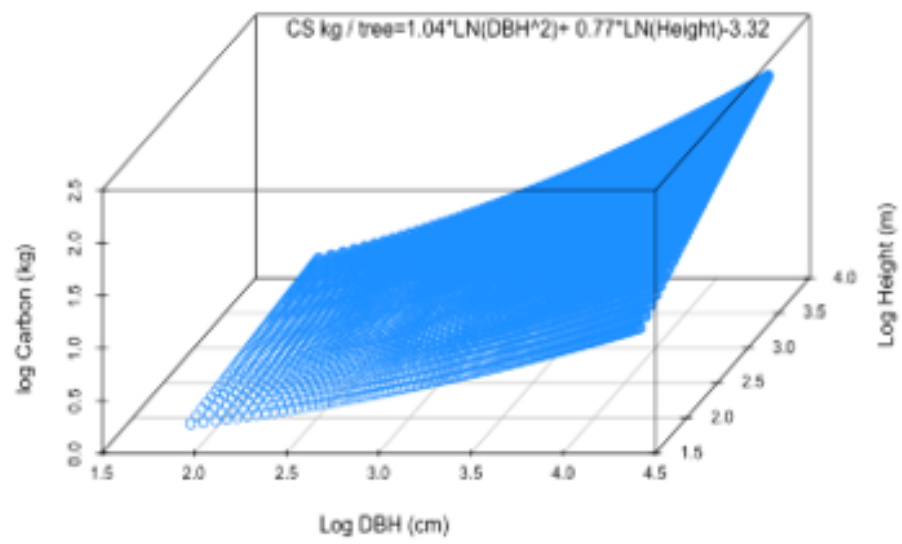

3d Scatter diagram for $\mathbf{2 5 - 5 0} \%$ CC

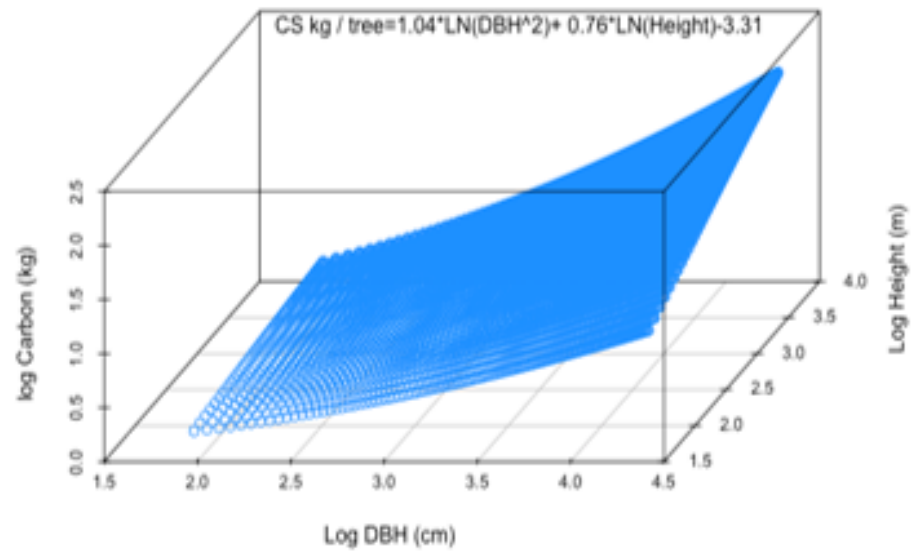

3d Seatter diagram for 75-100\% CC

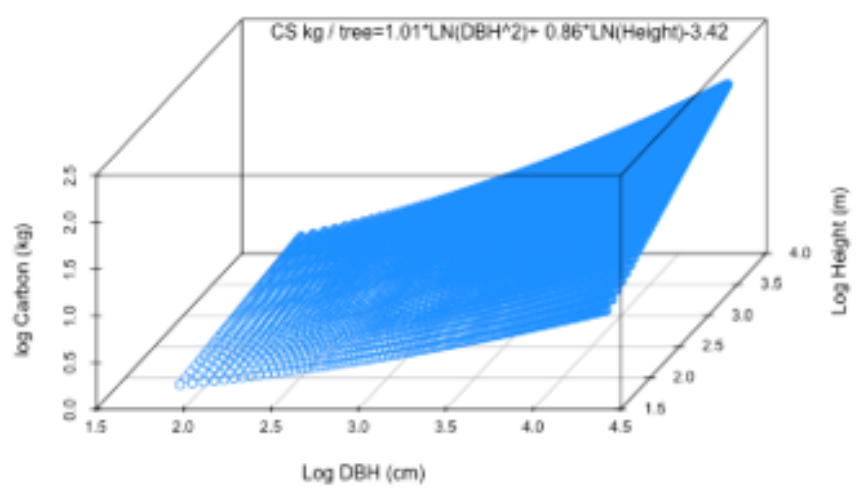

Figure 3

$3 \mathrm{~d}$ scatter diagram of model for estimating CS by crown cover class 
(a) $0-25 \%$ crown cover

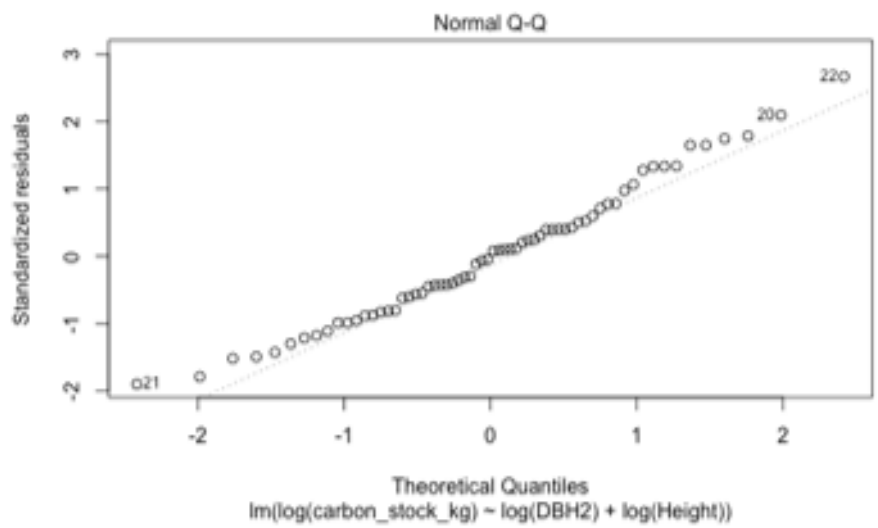

(c) $50-75 \%$

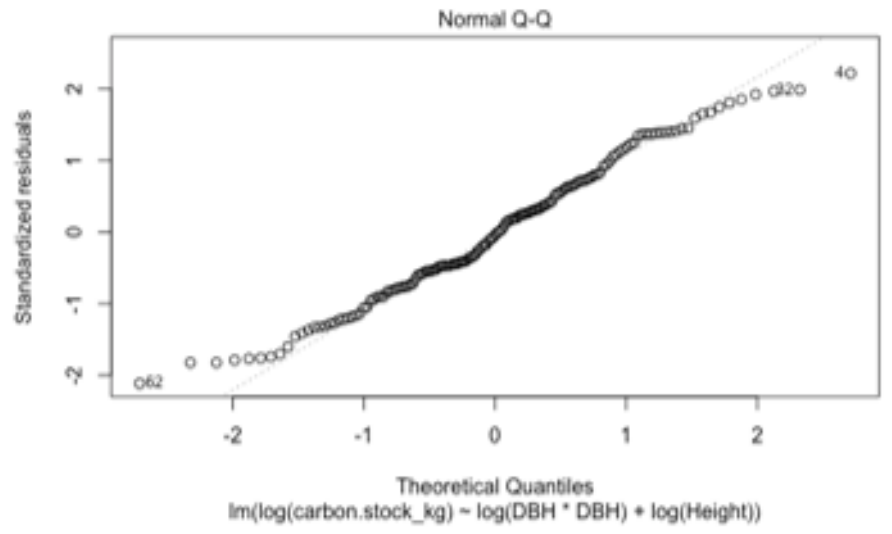

(b) $25-50 \%$

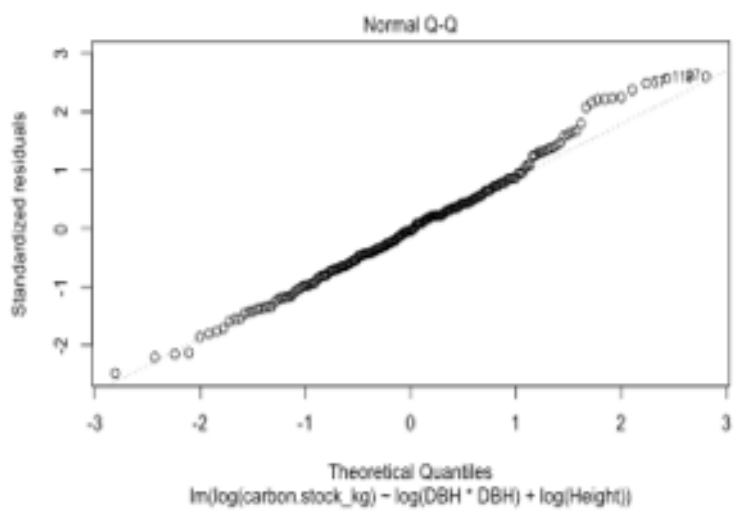

(d) More than $75 \%$

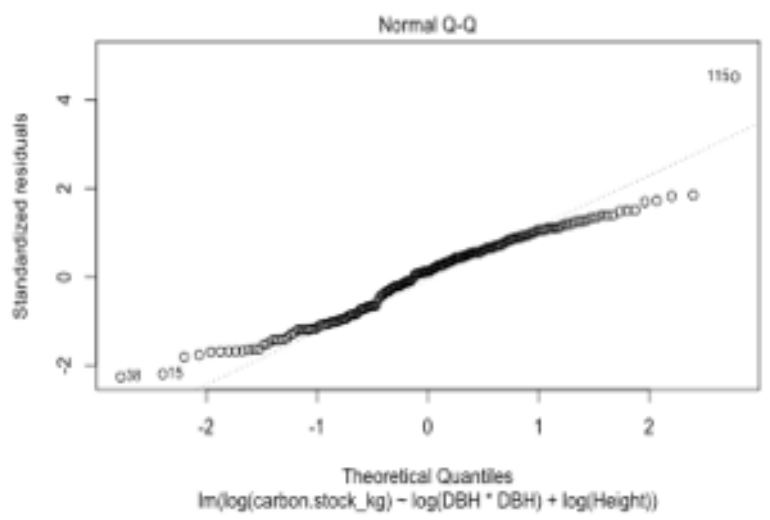

Figure 4

Normal Q-Q plot of residual of fitted model by crown cover percentage 


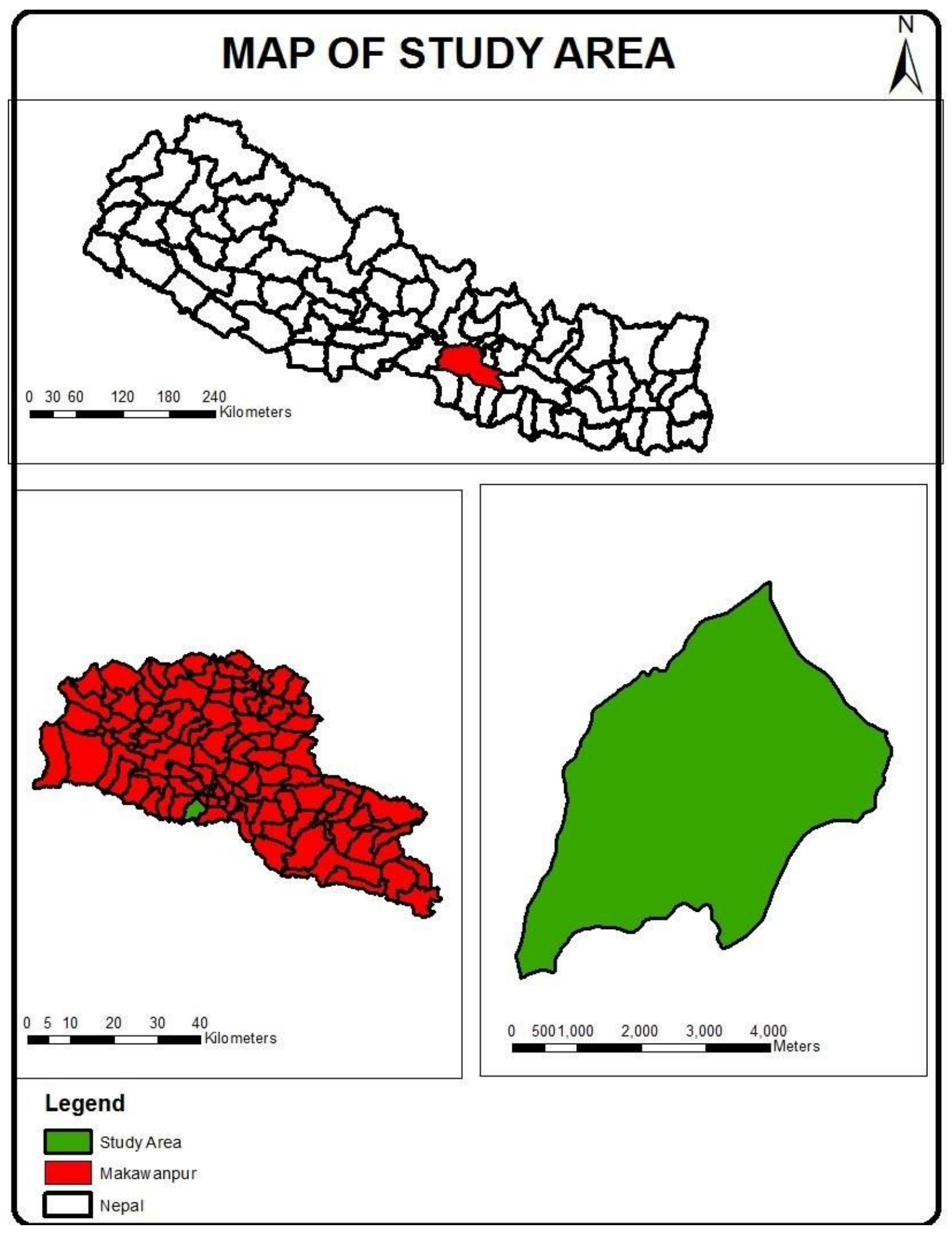

Figure 5

Map of study area 


\section{SAMPLE PLOT LAYOUT MAP}

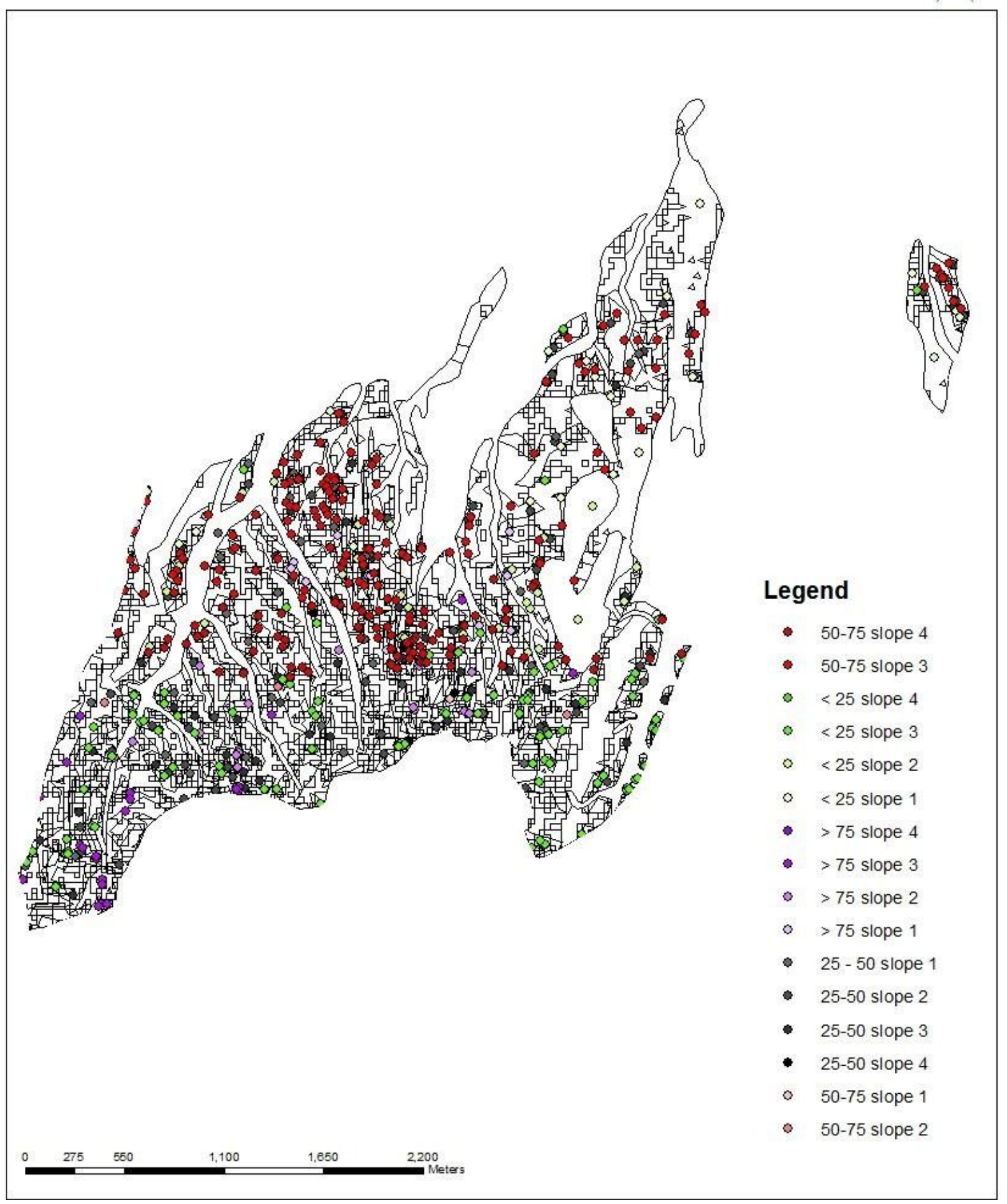

Figure 6

Sample plot layout

\section{Supplementary Files}

This is a list of supplementary files associated with this preprint. Click to download. 
- Formula.docx

Page 21/21 